\title{
Carp Connectin: Its Contents in White and Dark Muscles
}

\author{
Shigeru Kimura*, Yutaka AKashi*, and Minoru Kubota* \\ (Received September 4, 1978)
}

\begin{abstract}
The white and dark muscles of carp have been studied by a simple method which was devised for the isolation and determination of connectin, an elastic protein of muscle. The connectin contents in the white and dark muscles were estimated to be approximately $4.4 \%$ and $2.8 \%$ of the total muscle protein, respectively. When compared with the white muscle, however, the dark one was found to be rich in muscle stroma which was mainly composed of connectin and collagen. Connectin preparations of both muscles were almost free from connective tissue proteins, collagen and elastin, and exhibited a close similarity in their amino acid compositions.
\end{abstract}

Muscle tissues have been shown to contain an intracellular elastic protein, connectin, which is present in both myofibrils and muscle cell membranes $^{1-3 !}$. This fibrillar protein is responsible for the structural maintenance of myofibrils and the tension transmission from muscle to tendon ${ }^{31}$. The connectin contents of skeletal and cardiac muscle tissues were estimated to be about $0.5 \%$ and $1.5 \%$ of the fresh weight, respectively, but the methods for isolating connectin from muscles were very complicated." Thus, it seems that these methods are not suitable for the quantitative determination of connectin.

Recently we have isolated a white muscle connectin from carp ${ }^{4)}$, suggesting that the presence of hydroxyproline in connectin preparations previously reported ${ }^{1-31}$ may be due to contaminated collagen. In the present work, a simple method for the isolation and determination of connectin in muscles has been developed and used for a comparative study of connectins in white and dark muscles of carp.

\section{Experimental}

\section{Materials}

Carp Cyprinus carpio weighing $1-1.3 \mathrm{~kg}$ were killed by decapitation. The white and dark muscles were obtained from their dorsal lateral parts immediately after death.

\section{Preparation of Purified Connectin}

Purified connectin was prepared from the dorsal white muscle according to the alkaline method as briefly described in the previous paper" ${ }^{41}$. Approximately $100 \mathrm{~g}$ of the whole muscle tissue, after removal of fine bones, was homogenized with $300 \mathrm{ml}$ of the HASSELBACH-SCHNEIDER solution (0.6 K KCl, 0.1 $\mathrm{M}$ sodium phosphate buffer, pH 6.4, $10 \mathrm{~mm}$ sodium pyrophosphate, $\left.1 \mathrm{mM} \mathrm{MgCl}_{2}\right)^{5 !}$ and made up to $1 l$ with the same solution. Waterand salt-soluble proteins were extracted for $3 \mathrm{~h}$ under rapid stirring and removed by centrifugation at $10,000 \times \mathrm{g}$ for $10 \mathrm{~min}$. The precipitates were further treated with $500 \mathrm{ml}$ of the HASSELBACHSCHNEIDER solution for $15 \mathrm{~h}$ (twice) and collected by centrifugation as described above. Then, they were treated with $300 \mathrm{ml}$ of $0.6 \mathrm{M} \mathrm{KI}-0.06 \mathrm{M}$ $\mathrm{Na}_{2} \mathrm{~S}_{2} \mathrm{O}_{3}$ for $15 \mathrm{~h}$ (twice). During extraction of soluble proteins, most of white collagenous fibrils were entangled each other to form fibrous aggregates, so that they were carefully removed by forceps. The yellowish insoluble residues thus obtained were washed with distilled water and treated with $300 \mathrm{ml}$ of $1 \mathrm{~N}$ acetic acid for $15 \mathrm{~h}$ (twice), followed by treatment with $0.1 \mathrm{~N} \mathrm{NaOH}$ for $4 \mathrm{~h}$. The residues were finally neutralized and washed with $1 \mathrm{~N}$ acetic acid, and lyophilized. All operations were performed at $4-8^{\circ} \mathrm{C}$. The yield of connectin was about $120 \mathrm{mg}$ per $100 \mathrm{~g}$ fresh muscle.

\section{Determination of Collagen in Muscle Tissue}

Muscle tissues $(10 \mathrm{~g})$ were hydrolyzed with $6 \mathrm{~N}$ $\mathrm{HCl}$ at $110^{\circ} \mathrm{C}$ for $24 \mathrm{~h}$ and an aliquot of the hydrolysates was analyzed for hydroxyproline. The collagen content of muscle tissues was calculated on the basis of hydroxyproline content of 73.4 residues per 1000 amino acid residues for carp muscle collagen".

\section{Chemical Analyses}

The total protein content of muscle tissues was

* The Laboratory of Biochemistry, Tokyo University of Fisheries, Konan-4, Minato-ku, Tokyo 108 (木村 茂・赤司豊・久保田 楥：東京水産大学生物化学研究室). 
determined by the method of Lowry et al. ${ }^{71}$; whole muscle tissues except fine bones were completely solubilized by homogenizing with $1 \%$ sodium dodecyl sulfate- $8 \mathrm{M}$ urea and subsequent mixing for $24 \mathrm{~h}$ at $25-30^{\circ} \mathrm{C}$. The amount of protein in connectin preparations was estimated by a micro-KJELDAHL method on the basis of nitrogen content of $16.3 \%$ for carp connectin. This nitrogen content was obtained from the amino acid composition reported in this paper. Besides, the lipid content was estimated by the method of Folch et $a l^{81}$.

Amino acid analyses were performed using an amino acid analyzer, JEOL JLC-3BC liquid chromatograph. Samples were hydrolyzed with $6 \mathrm{~N}$ $\mathrm{HCl}$ at $110^{\circ} \mathrm{C}$ for $24 \mathrm{~h}$ under vacuum. Cystine and cysteine were determined as cysteic acid after performic acid oxidation ${ }^{21}$, followed by the acid hydrolysis as described above. Tryptophan was estimated by the amino acid analyzer on the alkaline hydrolysates of samples ${ }^{10 !}$.

\section{Results}

\section{A Simple Method for Determination of Carp Connectin}

Whole muscle tissues $(20 \mathrm{~g})$ were directly homogenized with $400 \mathrm{~m} l$ of $0.6 \mathrm{M} \mathrm{KCl}-0.02 \mathrm{~N} \mathrm{NaOH}$ in order to inactivate intracellular proteases. The resultant suspension was stirred for $24 \mathrm{~h}$ and filtered through a cheese cloth to remove collagen fibers and fine bones. The filtrate was centrifuged at $10,000 \times \mathrm{g}$ for $10 \mathrm{~min}$; about $98 \%$ of total soluble proteins was present in the supernatant. Then, the precipitates were treated with $200 \mathrm{ml}$ of the same alkaline solution for $24 \mathrm{~h}$ and collected by centrifugation as described above. This procedure was repeated twice. During these alkaline treatments, the fibrous aggregates of collagen appeared in a very small amount and were carefully removed by forceps. The residues thus obtained, connectin fraction, were thoroughly washed with distilled water, treated with $200 \mathrm{ml}$ of $0.2 \mathrm{~N}$ acetic acid for $12 \mathrm{~h}$, and then lyophilized. All operations were carried out at room temperature. The connectin fibrils of white and dark muscles behaved very differently during preparation. In the case of white muscle connectin, the swelling in $0.2 \mathrm{~N}$ acetic acid was much more pronounced. The protein content of connectin preparations was determined to be $70-80 \%$ of the dry weight and the remainder was found to consist of non-proteinous components, mainly lipids.

\section{Amino Acid Composition of Connectins}

The connectin preparations were analyzed for amino acids in order to evaluate their purity and to compare the two carp connectins. Table 1 exhibits that the white muscle connectin obtained by the simple method had an amino acid composition almost identical to that isolated by the original alkaline method. Moreover, there was no marked difference between the connectins of white and dark muscles in their composition. Hydroxyproline was absent or present in a yery small amount and desmosine was completely absent, indicating that collagen and elastin were effectively removed by this simple method. Thus, it appeared that the preparations consisted of almost connectin alone as a protein moiety. Incidentally, it is to be noted that the preparations contained non-proteinous components, mainly lipids, as much as $20-30 \%$ of the dry weight. If necessary, however, most of these lipids could be extracted by a mixture of chloroform and methanol.

Table 1. Amino acid composition of carp connectins

\begin{tabular}{|c|c|c|c|}
\hline \multirow[b]{3}{*}{ Hydroxyproline } & \multicolumn{2}{|c|}{ White muscle } & \multirow{2}{*}{ 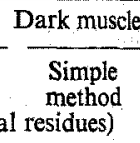 } \\
\hline & $\begin{array}{l}\text { Original } \\
\text { method } \\
\text { (residues) }\end{array}$ & $\begin{array}{c}\text { Simple } \\
\text { method } \\
1000 \text { total }\end{array}$ & \\
\hline & 0 & 0 & 1 \\
\hline Aspartic acid & 94 & 97 & 92 \\
\hline Threonine & 58 & 61 & 60 \\
\hline Serine & 51 & 52 & 50 \\
\hline Glutamic acid & 125 & 121 & 118 \\
\hline Proline & 51 & 59 & 63 \\
\hline Glycine & 70 & 72 & 79 \\
\hline Alanine & 78 & 75 & 80 \\
\hline Cystine/2 & 10 & 9 & 7 \\
\hline Valine & 70 & 73 & 76 \\
\hline Methionine & 27 & 25 & 24 \\
\hline Isoleucine & 60 & 61 & 61 \\
\hline Leucine & 80 & 78 & 81 \\
\hline Tyrosine & 33 & 31 & 26 \\
\hline Phenylalanine & 31 & 32 & 34 \\
\hline Tryptophan & 12 & 10 & 10 \\
\hline Lysine & 78 & 77 & $70^{\prime}$ \\
\hline Histidine & 20 & 18 & 18 \\
\hline Arginine & 51 & 49 & 50 \\
\hline
\end{tabular}

Connectin Contents in White and Dark Muscles

As shown in Table 2, the connectin contents in carp white and dark muscles were estimated to be approximately 4.4 and $2.8 \%$ of the total muscle protein, respectively, on the basis of protein contents of $18.0 \%$ for white muscle and of $13.3 \%$ for dark one. Muscle "stroma" is mainly composed 
Table 2. Contents of connectin and collagen in white and dark muscles of carp

\begin{tabular}{lccccc}
\hline & \multicolumn{2}{c}{ White muscle } & & \multicolumn{2}{c}{ Dark muscle } \\
\cline { 2 - 3 } & $\left(\frac{\mathrm{g}}{100 \mathrm{~g} \text { muscle }}\right)$ & $\left(\frac{\mathrm{g}}{100 \mathrm{~g} \text { protein }}\right)$ & & $\left(\frac{\mathrm{g}}{100 \mathrm{~g} \text { muscle }}\right)$ & $\left(\frac{\mathrm{g}}{100 \mathrm{~g} \text { protein }}\right)$ \\
\hline Connectin & 0.80 & 4.4 & 0.38 & 2.8 \\
Collagen & 0.54 & 3.0 & 1.14 & 8.6 \\
Total & 1.34 & 7.4 & 1.52 & 11.4 \\
\hline
\end{tabular}

Each value is given as an average of three different determinations.

of connectin and collagen, so that the collagen contents of muscles are also given in Table 2 . In contrast with the white muscle, the dark one was extremely rich in collagen. The total amount of connectin and collagen in the dark muscle was approximately $11.4 \%$ of the total muscle protein, which was one and half times as much as that in the white one. Further, it should be noted that the white muscle contained less collagen than connectin, while the dark one contained more collagen than connectin.

Then, white muscles were analyzed for connectin after storages at $-20^{\circ} \mathrm{C}$. The yields of connectin in the muscles frozen for 5 days and 1 month did not change significantly as compared with the control value.

\section{Discussion}

MARUYAMA et al. have found that connectin in chicken skeletal muscle was partially digested by intracellular proteases during the autolysis of muscle ${ }^{3 !}$. In view of this fact, it is very important to stop the autolysis at the first step of the procedures for determining connectin. In the present study, the inactivation of proteases was possibly achieved by the treatment of whole muscle tissue with a relatively strong alkaline solution $(0.6 \mathrm{M}$ $\mathrm{KCl}-0.02 \mathrm{~N} \mathrm{NaOH}$ ), because carp muscular alkaline protease was shown to be almost inactivated even at $\mathrm{pH} 10^{11}$. Therefore, the alkaline treatment has been applied to the simple method for the isolation and determination of connectin. Judging from the amino acid compositions, the connectin preparations obtained by the simple method have proved to be highly pure. Especially, collagen contamination was entirely removed from the preparations, while the complete removal of collagen from various connectin preparations has been known to be very difficult ${ }^{1,31}$.

Although the marked differences in the chemical composition of fish white and dark muscles were reported by many workers ${ }^{12}$, little is known about the difference in the protein composition of both muscles. Histological observations showed that connective tissue and sarcoplasm in dark muscle were generally present in much more abundance than those in white muscle ${ }^{181}$. Recently HosodA et $a .^{*}$ have reported the protein composition of carp muscles, indicating that white muscle was rich in myofibrils but poor in muscle stroma as compared with dark one. The present study has confirmed these results; that is, the higher content of connectin in the white muscle reflects the abundance of myofibrils. Amino acid analyses, however, revealed a close similarity between the connectins of both muscles. Further, the connectin content of carp white muscle, about $0.80 \%$ of fresh weight, was significantly higher than the reported values, $0.5-0.7 \%$, for rabbit and chicken skeletal muscles ${ }^{31}$, but was considerably lower than about $1.5 \%$ for bovine cardiac muscle ${ }^{31}$. On the contrary, the connectin content of carp dark muscle, about $0.38 \%$, was obviously less than those of rabbit and chicken skeletal muscles; this may be due to a lower proportion of myofibrils in the dark muscle.

At present, our knowledge of fish connectin is limited so far only to carp one. Thus, further comparative studies of fish connectin of other species are now in progress.

We wish to thank Prof. K. Maruyama of Chiba University for his valuable discussions. This work was supported in part by a grant from the Ministry of Education.

\section{References}

1) K. Maruyama, R. Natori, and Y. Nonomura: Nature, 262, 58-60 (1976).

2) K. Maruyama: J. Biochem., 80, 405-407 (1976).

* S. Hosoda, T. TsuchiYA, and J. J. Matsumoto: Oral presentation to the meeting of Japan. Soc. Sci. Fish., in October, Sendai, 1977. 
3) K. Maruyama, S. Matsubara, R. Natori, Y. Nonomura, S. Kimura, K. Ohashi, F. MuraKAMI, S. HANDA, and G. EGUCHI; J. Biochem., 82, 317-337 (1977).

4) S. Kimura, Y. AKASH, and M. Kubota: J. Biochem., 83, 321-323 (1978).

5) W. Hasselbach and G. Schneider: Biochem. $Z$., 321, 462-475 (1951).

6) M. Kubota and S. Kimura: Leather Chem., 21, 80-85 (1975).

7) O. H. Lowry, N. J. Rosebrough, A. L. FARR, and R. J. RANDALL: J. Biol. Chem., 193, 265-275 (1951).
8) J. Folch, M. Lees, and G. H. S. Stanley: J. Biol. Chem., 226, 497-509 (1957).

9) E. Schram, S. MOORE, and E. J. Brgwood: Biochem. J., 57, 33-37 (1954).

10) R. Knox, G. O. Kohler, R. Palter, and H. G. WALKER: Anal. Biochem., 36, 136-143 (1970).

11) K. Iwata, K. Kobashi, and J. Hase: Bull. Japan. Soc. Sci. Fish., 40, 189-200 (1974).

12) R. M. Love: The Chemical Biology of Fishes, Academic Press, London and New York, 1970, pp. 17-35.

13) H. Uematsu: Arch. Histol. Jap., 3, 1-9 (1951). 